\title{
In Situ/Subcellular Localization of Arabinogalactan Protein Expression by Fluorescent In Situ Hybridization (FISH)
}

\author{
Mário Luís da Costa, María-Teresa Solís, Pilar S. Testillano, \\ and Sílvia Coimbra
}

\begin{abstract}
The arabinogalactan proteins are highly glycosylated and ubiquitous in plants. They are involved in several aspects of plant development and reproduction; however, the mechanics behind their function remains for the most part unclear, as the carbohydrate moiety, covering the most part of the protein core, is poorly characterized at the individual protein level. Traditional immunolocalization using antibodies that recognize the glycosidic moiety of the protein cannot be used to elucidate individual proteins' distribution, function, or interactors. Indirect approaches are typically used to study these proteins, relying on reverse genetic analysis of null mutants or using a reporter fusion system. In the method presented here, we propose the use of RNA probes to assist in the localization of individual AGPs expression/mRNAs in tissues of Arabidopsis by fluorescent in situ hybridization, FISH. An extensive description of all aspects of this technique is provided, from RNA probe synthesis to the hybridization, trying to overcome the lack of specific antibodies for the protein core of AGPs.
\end{abstract}

Key words Whole mount, Immunolocalization, RNA probes, Arabidopsis, FISH, Arabinogalactan proteins

\section{Introduction}

Arabinogalactan proteins (AGPs) are cell wall glycoproteins, ubiquitous in the plant kingdom, that have been involved in several biological processes, namely, in sexual plant reproduction. The structure of these proteins has an $\mathrm{N}$-terminal sequence that targets the protein to the endoplasmic reticulum; a protein core rich in Pro/Hyp, Ala, Ser, and Thr; and a C-terminal sequence for the addiction of a glycosylphosphatidyl inositol (GPI) anchor. The protein core defines the different classes of AGPs as the classical, having this typical Pro/Hyp core between the $\mathrm{N}$ and the C-terminal sequence, the lysine-rich AGPs that have a lysine-rich domain, the fasciclin-AGPs (FLAs) with fasciclin-like domains and 
finally the AG peptides containing small protein cores with no more than 30 amino acid residues [1].

For the past twenty years, several approaches have been developed to try to learn more about the biological way of action of this important class of proteins, but exactly due to their structure, with more than $90 \%$ of the molecule being sugars, this has been a hard task to perform. AGP glycans are polysaccharide chains $\mathrm{O}$-glycosidically linked to the Hyp residues. Initial studies used the synthetic Yariv reagent that blocks AGP function and clearly demonstrated the importance of these proteins in several biological processes. The use of monoclonal antibodies available for the glycosidic part of the AGPs has shown that AGPs could be used as molecular markers for different stages of plant development and for different cell/tissues involved in sexual plant reproduction and embryogenesis [2-6].

The presence of the GPI anchor that binds AGPs to the plasma membrane, facing the cell wall, the possibility of cleavage by specific phospholipase C of the GPI anchor, in association with the complex sugar architecture that surrounds the protein core, and specific cell and tissue localization make these molecules important candidates for signaling events [7].

This chapter describes in detail one of the different procedures to study AGPs involved in sexual plant reproduction. The immunocytochemistry techniques using the available collection of antibodies that recognize the different sugar epitopes present in AGPs [8] is very useful to impart important roles for these proteins in sexual plant reproduction [2-6,9], but lack resolving power. The use of other important molecular techniques becomes essential for unraveling the involvement of particular AGPs in a particular biological process. An inportant tool to learn about the function of a particular protein is to use reverse genetic analysis every time that null mutants are available $[10,11]$. Also crucial for giving important results are the techniques of promoter analysis, using different type of reporter genes [12]. In this chapter we will go in detail over the technique for fluorescent in situ hybridization of AGP transcripts, a method that allows detection of specific mRNA sequences of AGPs with high sensitivity and accuracy, at the individual cell level.

The study of AGPs involvement in Arabidopsis thaliana ovule development is a challenging process, where timing and optical resolution are key to success. In the complex structure of the ovule, the gametophyte tissues are inaccessible and surrounded by a double layer of sporophyte integuments, a situation/fact that adds complexity to this study. Tools have been developed to ease this ordeal, like the use of reporter fused promoters or cellular terminator together with confocal and phase contrast microscopy. But these techniques are complex and time consuming, requiring 
besides the preparation of constructs, transformation and selection of transformed offspring, and yet a few more weeks for plantlets to reach maturity and start producing flowers. A swifter way to determine a gene expression pattern is by in situ hybridization $[4,13,14]$.

In situ hybridization is traditionally a technique that allows for the detection and localization of genes and their transcripts [13]. Originally this technique relied on paraffin embedding and sectioning, a time-consuming technique that required optimization for the tissue or organ under study, due to variation on cell wall thickness and permeability; moreover, the structural preservation of cells and tissues after processing for paraffin embedding is very poor due to high temperature and exhaustive dehydration with potent solvents used during the procedure. Additionally the probes were labeled with harmful radioisotopes for detection $[15,16]$; the later substitution of these radioactive materials by digoxigenin- [17-19] or alkaline phosphatase-labeled oligonucleotides [20] made this technique safer and more user friendly; however, the use of alkaline phosphatase or peroxidase needed optimization of the reaction time, as the overreaction can create artifacts. Additionally it was very difficult to evaluate the state of preservation of the tissues. With further development of highly stable and sensible fluorochromes that can be conjugated to a wide range of reporter molecules, as antibodies, nucleotides, biotin, or digoxigenin, cell biology localization techniques highly increased their sensitivity and field of application; this fact, together with the development of confocal laser scanning microscopy, opened the way for tracking specific protein and gene expression in tissues and organs at the single cell level, also in plant biology research [21].

In the case of plants, one of the challenges of these in situ methodologies has been to overcome the limitations associated with specific features of most plant cells such as the presence of cell wall which hinders, at least partially, penetration of antibodies and probes to subcellular targets. Regarding in situ localization methods for plant ovaries, the situation is even more complex, as stated before, due to small size and inaccessibility of the gametophyte inside tissues.

With the revised method presented here, localization of transcripts in Arabidopsis ovules is made easier, more sensitive, and less time-consuming; by making a whole-mount fixation, probe hybridization and detection, we eliminate the need for embedding and sectioning, reducing time and difficulty of the procedure. RNA probes have the advantage that RNA-RNA hybrids are very thermostable and are resistant to digestion by RNases. This allows for post-hybridization digestion with RNase to remove nonhybridized RNA and therefore reduces the possibility of background staining. Appropriate fixation and permeabilization are essential steps to optimally preserve cells and RNAs for efficient hybridization, messenger RNA detection, and high cellular preservation and 
visualization. Also the use of fluorescent conjugated antibodies to localize digoxigenin-labeled hybrids enables higher sensitivity, clearer images and higher resolution of labeling at a subcellular level $[22,23]$, its combination with DAPI staining [24] provides additional evaluation of cell structure and integrity.

\section{Materials}

\subsection{Buffers}

2.2 Culture Media
1. DNA Extraction Buffer: Tris- $\mathrm{HCl}$ pH $7.5200 \mathrm{mM}, \mathrm{NaCl}$ $250 \mathrm{mM}$, EDTA $25 \mathrm{mM}$, SDS $0.5 \%$ (w/v), in ${ }_{\mathrm{dd}} \mathrm{H}_{2} \mathrm{O}$. Always prepare fresh.

2. RNA dilution buffer: $6 \times$ SSC (see Buffers 2.1.6), 3.2\% (w/v) paraformaldehyde in RNase-free $\mathrm{H}_{2} \mathrm{O}$. Always prepare fresh.

3. PBS (phosphate-buffered saline): $\mathrm{KCl} 2.7 \mathrm{mM}, \mathrm{NaCl} 137 \mathrm{mM}$, $\mathrm{Na}_{2} \mathrm{HPO}_{4} 10 \mathrm{mM}, \mathrm{KH}_{2} \mathrm{PO}_{4} 1.8 \mathrm{mM}$. Adjust $\mathrm{pH}$ to 7.4 with $\mathrm{HCl}$. Filter-sterilize or autoclave.

4. Hybridization buffer (see Table 1).

5. 50× Denhardt's: BSA 1\% (w/v), Ficoll 400 1\% (w/v), Polyvinylpyrrolidone $1 \%(\mathrm{w} / \mathrm{v})$, in RNase-free water. Filter-sterilize with a $0.2 \mu \mathrm{M}$ filter. Aliquot and store at $-20^{\circ} \mathrm{C}$.

6. $20 \times$ SSC: trisodium citrate $300 \mathrm{mM}$, sodium chloride $3 \mathrm{M}$ in $\mathrm{RNase}$-free $\mathrm{H}_{2} \mathrm{O}$. Adjust $\mathrm{pH}$ to 7.0 with $1 \mathrm{M} \mathrm{HCl}$. Aliquot and store at $-20{ }^{\circ} \mathrm{C}$.

1. LB/ampicillin/IPTG/X-Gal culture plates: Bacto tryptone $1 \%$ $(\mathrm{w} / \mathrm{v})$, Bacto yeast extract $0.5 \%(\mathrm{w} / \mathrm{v}), \mathrm{NaCl} \mathrm{l} \%(\mathrm{w} / \mathrm{v})$, Bacto agar $1.5 \%(\mathrm{w} / \mathrm{v})$, in ${ }_{\mathrm{dd}} \mathrm{H}_{2} \mathrm{O}$. Adjust $\mathrm{pH}$ to 7.5 with $\mathrm{NaOH}$.

\section{Table 1}

\section{Hybridization buffer}

\begin{tabular}{|c|c|c|c|c|c|c|c|}
\hline \multirow[b]{2}{*}{ Stocks } & \multirow{2}{*}{$\begin{array}{l}\text { Final } \\
\text { concentration }\end{array}$} & \multicolumn{5}{|c|}{ Volume of hybridization buffer } & \multirow{2}{*}{$\begin{array}{l}\text { Mixing } \\
\text { order }\end{array}$} \\
\hline & & $50 \mu \mathrm{L}$ & $100 \mu \mathrm{L}$ & $150 \mu \mathrm{L}$ & $200 \mu \mathrm{L}$ & $250 \mu \mathrm{L}$ & \\
\hline RNase-free $\mathrm{H}_{2} \mathrm{O}$ & n.a. & $5.5 \mu \mathrm{L}$ & $11 \mu \mathrm{L}$ & $16.5 \mu \mathrm{L}$ & $22 \mu \mathrm{L}$ & $27.5 \mu \mathrm{L}$ & 1 \\
\hline $\mathrm{NaCl} 5 \mathrm{M}$ & $300 \mathrm{mM}$ & $3 \mu \mathrm{L}$ & $6 \mu \mathrm{L}$ & $9 \mu \mathrm{L}$ & $12 \mu \mathrm{L}$ & $15 \mu \mathrm{L}$ & 2 \\
\hline $\begin{array}{l}\text { Tris-EDTA solutions } \\
\text { 3.1.1 }\end{array}$ & $10 \mathrm{mM} / 1 \mathrm{mM}$ & $5 \mu \mathrm{L}$ & $10 \mu \mathrm{L}$ & $15 \mu \mathrm{L}$ & $20 \mu \mathrm{L}$ & $25 \mu \mathrm{L}$ & 3 \\
\hline $50 \times$ Denhardt's & $1 \times$ & $1 \mu \mathrm{L}$ & $2 \mu \mathrm{L}$ & $3 \mu \mathrm{L}$ & $4 \mu \mathrm{L}$ & $5 \mu \mathrm{L}$ & 4 \\
\hline Formamide & $50 \%$ & $25 \mu \mathrm{L}$ & $50 \mu \mathrm{L}$ & $75 \mu \mathrm{L}$ & $100 \mu \mathrm{L}$ & $125 \mu \mathrm{L}$ & 5 \\
\hline $50 \%$ Dextran sulfate & $10 \%$ & $10 \mu \mathrm{L}$ & $20 \mu \mathrm{L}$ & $30 \mu \mathrm{L}$ & $40 \mu \mathrm{L}$ & $50 \mu \mathrm{L}$ & 6 \\
\hline tRNA $(20 \mathrm{mg} / \mathrm{mL})$ & $200 \mu \mathrm{g} / \mathrm{mL}$ & $0.5 \mu \mathrm{L}$ & $1 \mu \mathrm{L}$ & $1.5 \mu \mathrm{L}$ & $2 \mu \mathrm{L}$ & $2.5 \mu \mathrm{L}$ & 7 \\
\hline
\end{tabular}


Sterilize by autoclaving, let cool to $45{ }^{\circ} \mathrm{C}$, and add filter sterilized ampicillin to $100 \mu \mathrm{g} / \mathrm{mL}$, IPTG to $0.1 \mathrm{mM}$, and X-Gal (in DMF) $30 \mu \mathrm{g} / \mathrm{mL}$. Plate immediately and store at $4{ }^{\circ} \mathrm{C}$, wrapped in aluminum foil.

2. SOC: Bacto Tryptone 2\% (w/v), Bacto yeast extract $0.5 \%$ (w/v), $\mathrm{NaCl} 10 \mathrm{mM}, \mathrm{KCl} 2.5 \mathrm{mM}, \mathrm{MgCl}_{2} 10 \mathrm{mM}, \mathrm{MgSO}_{4}$ $10 \mathrm{mM}$, glucose $10 \mathrm{mM}$. Sterilize by autoclaving. SOC culture medium is used for the recovery of transformed bacterial cells.

\subsection{Solutions}

1. TE: Tris- $\mathrm{HCl}$ pH $7.510 \mathrm{mM}$, EDTA $1 \mathrm{mM}$, in ${ }_{\mathrm{dd}} \mathrm{H}_{2} \mathrm{O}$. This lightly saline solution helps to devolve DNA.

(a) Tris-EDTA: Tris-HCl pH $7.5100 \mathrm{mM}$, EDTA $10 \mathrm{mM}$, in RNase-free ${ }_{d d} \mathrm{H}_{2} \mathrm{O}$. Aliquot and store at $-20{ }^{\circ} \mathrm{C}$. This variation of the TE solution is used in the hybridization buffer.

2. Miniprep solution 1: TRIS pH $8.025 \mathrm{mM}$, EDTA pH 8.0 $10 \mathrm{mM}$, glucose $50 \mathrm{mM}$, in ${ }_{\mathrm{dd}} \mathrm{H}_{2} \mathrm{O}$. Always prepare fresh.

After removing the growing medium in the first step of the plasmid purification protocol, the cells must be suspended in a uniform manner for the alkaline lysis to take place. This solution will allow just that.

3. Miniprep Solution 2: SDS $1 \%(\mathrm{w} / \mathrm{v}), \mathrm{NaOH} 0.2 \mathrm{~N}$, in ${ }_{\mathrm{dd}} \mathrm{H}_{2} \mathrm{O}$. This solution will burst bacterial cell by attacking the cell membrane with a detergent and high $\mathrm{pH}$. In this way the plasmids will be released into the solution. Always prepare fresh.

4. Miniprep Solution 3: KOAc $3 \mathrm{M}$, glacial acetic acid $2 \mathrm{M}$, in ${ }_{\text {dd }} \mathrm{H}_{2} \mathrm{O}$. Store at $4{ }^{\circ} \mathrm{C}$, check for contaminants before use. After bursting the cells, proteins and all other cellular molecules are released to the alkaline solution. This solution will neutralize the solution and precipitate SDS, proteins, and other impurities.

5. Miniprep Solution 4: RNase (Thermo, EN0531) to $20 \mu \mathrm{g} / \mathrm{mL}$ in TE (see Solutions 2.3.1). If possible prepare fresh. RNA copurification is common with this miniprep protocol and can be a problem to the restriction of the purified plasmids. A simple and easy way to get rid of this contamination is a simple treatment with RNase.

6. BSA 5\%: bovine serum albumin $5 \%(\mathrm{w} / \mathrm{v})$ in PBS (see Buffers 2.1.3). Aliquot and store at $-20{ }^{\circ} \mathrm{C}$. Dilute at a ratio of $1: 5$ in PBS to prepare $1 \%$ BSA. Bovine serum albumin is used as a blocking agent in the immunodetection reactions.

7. Fixative Solution: paraformaldehyde 4\% (w/v), Tween $200.001 \%(\mathrm{v} / \mathrm{v})$, in PBS (see Buffers 2.1.3). Always prepare fresh. To prepare $1 \%$ paraformaldehyde in PBS make a $1: 4$ 
dilution of this solution in PBS. This fixative solution is used to prevent degradation of cellular content, prior to the dehydration step. It also helps with mRNA unfolding, easing RNA probe ligation.

8. Methanol series in PBS: Make methanol dilutions of $70 \%(\mathrm{v} / \mathrm{v})$, $50 \%(\mathrm{v} / \mathrm{v})$, and $30 \%(\mathrm{v} / \mathrm{v})$, in PBS (see Buffers 2.1.3). Store at $-20{ }^{\circ} \mathrm{C}$. During the dehydration-rehydration process a methanol series is used to dehydrate and rehydrate the dissected pistils. This step serves as a first permeabilization to help further accessibility of probes to intracellular targets. The final dehydration prior to hybridization eliminates excess water in tissues that would hinder hybridization reaction; it also helps eliminating any remaining active enzyme used during permeabilization.

9. Macerozyme R-10: Macerozyme R-10* (cat.no. 28302, SERVA Germany) $2 \%(\mathrm{w} / \mathrm{v})$, in RNase-free $\mathrm{H}_{2} \mathrm{O}$. Filtersterilize with a $0.45 \mu \mathrm{M}$ Filter, Aliquot and store at $-20{ }^{\circ} \mathrm{C}$. Macerozyme R-10 has various enzymatic activities to partially degrade cell wall components. Cell walls are a principal barrier for probe penetration; treating the tissue with a pectinase and cellulase cocktail makes cell walls become more permeable without loosening their integrity.

*Activity: pectinase $0.5 \mathrm{U} / \mathrm{mg}$, hemicellulase $0.25 \mathrm{U} / \mathrm{mg}$, cellulase $0.1 \mathrm{U} / \mathrm{mg}$.

10. DAPI staining solution: To make a $5 \mathrm{mg} / \mathrm{mL}$ DAPI stock solution (14.3 $\mathrm{mM}$ for the dihydrochloride DAPI or $10.9 \mathrm{mM}$ for the dilactate DAPI), dissolve $10 \mathrm{mg}$ in $2 \mathrm{~mL}$ of deionized water $\left(\mathrm{dH}_{2} \mathrm{O}\right)$ or dimethylformamide (DMF). You may have to sonicate the dihydrochloride DAPI as it is harder to dissolve in water than the dilactate DAPI. Dilute the DAPI stock solution to $300 \mathrm{nM}$ in PBS, and use about $20 \mu \mathrm{L}$ directly over the pistil-containing wells. DAPI ( $4^{\prime}, 6$-diamidino-2-phenylindole) is a very useful stain for the nucleus. In this version of fluorescent in situ localization it serves a dual purpose, first it will help to locate the cell nucleus. The labeling of DAPI and the probe should not overlap since in the conditions used the RNA probe should have no affinity to the nucleic DNA. Observation of the nucleus integrityby DAPI staining, permits proper evaluation of the hybridization signal in the cytoplasm and good cell structural preservation.

11. Mowiol mounting medium: Weigh $6 \mathrm{~g}$ of analytical-grade glycerol in a $50 \mathrm{~mL}$ disposable plastic conical centrifuge tube. Add 2.4 g of Mowiol 4-88 (sigma, 81381) and stir thoroughly to mix the Mowiol with the glycerol. Add $6 \mathrm{~mL}$ of distilled water and let the solution rest at room temperature for $2 \mathrm{~h}$. Mix in $12 \mathrm{~mL}$ of $0.2 \mathrm{M}$ Tris buffer $(2.42 \mathrm{~g}$ Tris $/ 100 \mathrm{~mL}$ water, adjust $\mathrm{pH}$ to 8.5 with $\mathrm{HCl}$ ) and incubate the solution in a 
water bath at $50{ }^{\circ} \mathrm{C}$ for $10 \mathrm{~min}$ with occasional stirring to dissolve the Mowiol. Clarify the mixture by centrifugation at $5000 \times g$ for $15 \mathrm{~min}$. Aliquot and store at $-20{ }^{\circ} \mathrm{C}$.

The solution is stable, and the $\mathrm{pH}$ is retained for at least 12 months at $-20{ }^{\circ} \mathrm{C}$, and for about a month at room temperature. Mowiol is a water-soluble hydrocolloid mucoadhesive based on poly(vinyl alcohol) that carries both the advantage of antifade properties and creating a solid seal of the final preparation. Stained slides mounted with Mowiol retain fluorescence when stored at $4{ }^{\circ} \mathrm{C}$ in the dark.

\subsection{Equipment}

1. 0.2 and $1.5 \mu \mathrm{L}$ centrifuge tubes.

2. 15 and $50 \mathrm{~mL}$ conical tubes.

3 . Centrifuge.

4. Fine-tipped forceps.

5. G26 (or higher gauge) hypodermic needles.

6. Humidity chamber (see Fig. 1).
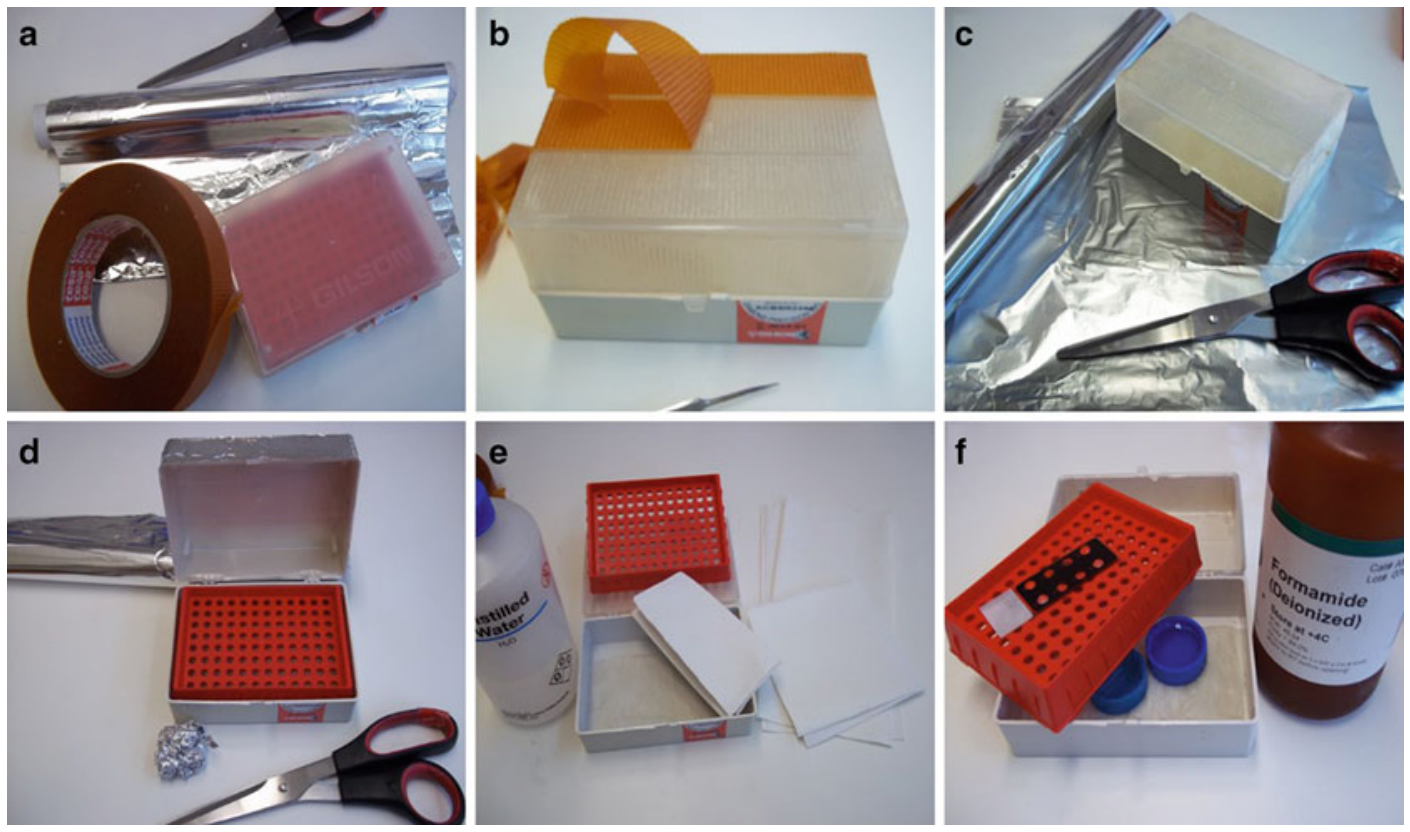

Fig. 1 Setting a hybridization box. A humidity box is a fundamental tool in this procedure; it will avoid the evaporation of solutions during the incubation periods. To make one use a tip box, tin foil, and some doublefaced duct tape (a). Cover the top of the box with a layer of double-faced duct tape (b) then cover it with aluminum foil (c). Remove the excess foil (d) and remove the tip holding rack. In the bottom of the box place some damp paper towels (e). To make it suitable for the hybridization incubation place some $50 \mathrm{~mL}$ conical tubes caps field of formamide on the bottom of the box (f) This will saturate the air in the sealed chamber and reduce the evaporation of the hybridization solution, as after the hot incubation the leads can be easily removed to minimize the exposure to formamide vapors. Put back the tip holding rack; it will serve as a nice support for the slides. 
2.5 Enzymes

2.6 Commercial Kits
7. Hybridization oven.

8. Vacuum filtering flask.

9. Micropipettes.

10. NanoDrop ${ }^{\circledR}$.

11. Parafilm ${ }^{\circledR}$.

12. Teflon-coated reaction slides.

13. Thermocycler.

14. Vacuum pump.

15. Vacuum chamber.

16. Vortex.

1. Taq-based PCR system.

2. PstI and NcoI.

1. NBT-BCIP ${ }^{\circledR}$ solution (sigma, 72091).

2. pGEM $^{\circledR}$-T Easy cloning kit (Promega, Al360).

3. JM109 Competent Cells (Promega, L2005).

4. T7/SP6 DIG-RNA labeling kit (Roche, Cat. No. 11175025910$)$.

\section{Method}

This extended protocol for fluorescent in situ hybridization is a broad guide through all the steps from the extraction of the template DNA, to the synthesis of the probe. Finally the hybridization itself will be divided in preparation of the hybridization slides, probe hybridization, and probe detection.

3.1 Probe

Preparation
Probe design and synthesis is one of the most important steps for a successful in situ hybridization. Careful planning must be made to choose the correct probe sequence and length. Has it will affect the probe specificity and penetration ability.

AGPs are a diverse group of proteins [1] where splicing is generally absent, making the selection of an mRNA region to use has target for a RNA probe fairly simple. The design process must include, however, a careful verification of the selected sequence specificity, the most preserved sequences being the $\mathrm{N}$-terminal and GPI anchor signals. AG-Peptides due to their very short sequence are most challenging for this task, but short specific probe sequences can be obtained. The optimal length for a RNA probe is between 200 and 1500 bases. 


\subsection{DNA Extraction}

\section{3 pGEM Cloning}

\subsubsection{Cloning PCR}

Products with $P G E M^{\mathbb{R}}-T$ Easy Vectors (Promega, A1360)
Another aspect of the use of RNA probes is their sensitivity to degradation; an extra effort must be made to keep all materials and solutions RNase free. A minute amount of RNase may destroy a complete batch of precious RNA probe.

Genomic DNA will serve has a template to create the probe sequence that will be inserted in a plasmid, that in turn will be used to synthesize the RNA probe.

The first step will be to extract DNA. In the following method we propose to use a rapid and simple method to isolate genomic DNA suitable for PCR amplification, based on the method of Edwards et al. [25].

All steps are performed at room temperature and centrifugations are at $13,000 \times \mathfrak{g}$.

1. Prepare the DNA Extraction Buffer (see Buffers 2.1.1).

2. Use the lid of a $1.5 \mathrm{~mL}$ centrifuge tube to punch out a disc from a young leaf into the tube (see Note 6.1a-b), and grind it thoroughly in a small mortar and pestle. Immediately add $400 \mu \mathrm{L}$ of extraction buffer, and vortex for $5 \mathrm{~s}$ (see Note 6.1.c).

3. Spin at max RPM for 2 min to pellet the tissues debris, and transfer $400 \mu \mathrm{L}$ of the supernatant into a fresh $1.5 \mathrm{~mL}$ centrifuge tube (avoid taking debris from the pellet). Add $350 \mu \mathrm{L}$ isopropanol, mix by gently inverting the tubes a few times and leave at room temperature for $2 \mathrm{~min}$. Then spin for $5 \mathrm{~min}$ at full speed to pellet the DNA.

4. Remove all the supernatant and let air dry for a few minutes. (Do not let the pellet get too dry, otherwise it will be very difficult to suspend the genomic DNA.)

5. Dissolve the pellet in $50 \mu \mathrm{L} \mathrm{TE}$ (solution 2.3.1), or PCR grade $\mathrm{H}_{2} \mathrm{O}$ by gentle shaking. DO NOT VORTEX. Check the integrity of the gDNA by agarose gel electrophoresis (see Note 6.1. d).

After extracting the gDNA can be used as a template to amplify the target gene sequences by PCR using an enzyme with $3^{\prime}$ adenylation activity (see notes pGEM cloning 6.2).

Perform a PCR cleanup and quantify your PCR product.

1. Set up ligation reactions, with $5 \mu \mathrm{L}$ of $2 \times$ Rapid Ligation Buffer, $1 \mu \mathrm{L}$ of pGEM $^{\circledR}$-T Easy Vector $(50 \mathrm{ng}), 37.5 \mu \mathrm{g}$ of purified PCR product, $1 \mu \mathrm{L}$ of T4 DNA Ligase, and PCR grade $\mathrm{H}_{2} \mathrm{O}$ to a final volume of $10 \mu \mathrm{L}$. Vortex the $2 \times$ Rapid Ligation Buffer vigorously before use (see Note 6.2.b).

2. Mix the reactions by pipetting (see Note 6.2.c). Incubate overnight at $4{ }^{\circ} \mathrm{C}$ to maximize ligations. 
3.3.2 Transformation of JM109 High Efficiency Competent Cells
3.3.3 Miniprep

Protocol [28]
1. Prepare LB/ampicillin/IPTG/X-Gal plates (see Culture media 2.2.1).

2. Centrifuge the ligation reactions briefly. Add $2 \mu \mathrm{l}$ of each ligation reaction to a sterile $1.5 \mathrm{~mL}$ tube on ice. Prepare a control tube with $0.1 \mathrm{ng}$ of uncut plasmid.

3. Place the JM109 Competent Cells (Promega, L2005) in an ice bath until just thawed $(\sim 5 \mathrm{~min})$. Mix cells by gently flicking the tube. Carefully transfer $50 \mu \mathrm{L}$ of cells to the ligation reaction tubes. Use $100 \mu \mathrm{L}$ of cells for the uncut DNA control tube. Gently flick the tubes and incubate on ice for $20 \mathrm{~min}$. Then Heat-shock the cells for $45-50 \mathrm{~s}$ in water bath at exactly $42{ }^{\circ} \mathrm{C}$. DO NOT SHAKE. Immediately return the tubes to the ice. After 2 min add $950 \mu \mathrm{L}$ room temperature SOC medium ( see Culture media 2.2.2) to the ligation reaction transformations and $900 \mu \mathrm{L}$ to the uncut DNA control tube. Incubate for $1.5 \mathrm{~h}$ at $37^{\circ} \mathrm{C}$ with shaking ( 150 r.p.m.).

4. Plate $100 \mu \mathrm{L}$ of each transformation culture onto duplicate LB/ampicillin/IPTG/X-Gal plates. For the uncut DNA control, a 1:10 dilution with SOC is recommended. Incubate all plates overnight at $37^{\circ} \mathrm{C}$. Select white colonies.

5. Use M13 primers in conjugation with your reverse primer to confirm to orientation of your insert. This will determine which reaction T7 RNA Polymerase or SP6 RNA Polymerase will produce your antisense (or detection) probe $[26,27]$ (see Note 6.2.d).

6. After this initial screening select one colony and proceed with multiplication of the probe containing plasmid.

The plasmid containing the probe sequence will be used as a template for SP6 and T7 RNA polymerase $[26,27]$. We will now proceed with the multiplication and purification of the probe containing plasmid.

1. Inoculate $5 \mathrm{~mL}$ of $\mathrm{LB} / \mathrm{amp}(75 \mu \mathrm{g} / \mathrm{mL})$ (see Note 6.3.a) overnight at $37^{\circ} \mathrm{C}$ with vigorous agitation.

2. Fill a $1.5 \mathrm{~mL}$ Eppendorf tube and centrifuge for $1 \mathrm{~min}$ at $10000 \times g($ see Note 6.3.b). Discard the supernatant and repeat until you have spun down $5 \mathrm{~mL}$.

3. Then suspend the pellet in $100 \mu \mathrm{L}$ of Miniprep solution 1 ( see Solutions 2.3.2) and mix in $20 \mu \mathrm{L}$ of $10 \mathrm{mg} / \mathrm{mL}$ of lysozyme. Let stand at room temperature for $2 \mathrm{~min}$ (for $1 \mathrm{~mL}$ : $0.01 \mathrm{~g}$ Lysozyme in $1 \mathrm{~mL} 0.250 \mathrm{mM}$ tris $\mathrm{pH} 8.0$ ).

4. Add $200 \mu \mathrm{L}$ of Miniprep solution 2 (see Solutions 2.3.3) mix well and place on ice for $5 \mathrm{~min}$, then add $150 \mu \mathrm{L}$ of Miniprep solution 3 (material solution 3.4) vortex gently and place back on ice for $5 \mathrm{~min}$. 
5. Centrifuge at $4{ }^{\circ} \mathrm{C}$ for $5 \mathrm{~min}$ at $12000 \times g$. Transfer the supernatant to a new tube (see Note 6.3.c).

6. Add $400 \mu \mathrm{L}$ of phenol-chloroform. Vortex and centrifuge at $4{ }^{\circ} \mathrm{C}$, for $2 \mathrm{~min}$ at $12000 \times g$.

7. Transfer the aqueous upper phase to a new tube (see Note 6.3. d). Add $1 \mathrm{~mL}$ of $100 \%$ ethanol at room temperature.

8. Leave to stand for $2 \mathrm{~min}$ at room temperature.

9. Centrifuge at $12000 \times g$ for $5 \mathrm{~min}$, pour off the ethanol and let the pellet dry.

10. Dissolve the pellet in $50 \mu \mathrm{L}$ of TE/RNase ( see Solutions 2.3.1), quantify your purified Plasmid by NanoDrop and send one sample for sequencing.

\subsection{RNA Probe Synthesis and Labeling}

3.4.1 Linearize the Plasmid

3.4 .2

Digoxigenin-Labeled RNA Probe Synthesis
In the following steps the purified plasmid will be prepared for the synthesis and labeling of the probe with the T7/SP6 DIG-RNA labeling kit (Roche, Cat. No. 11175025910) (see Note 6.4.a).

For the proper synthesis of the RNA probe by T7 or SP6 RNA polymerase the plasmid most first be linearized, or it will produce uneven sized and possibly unspecific sequences.

1. Carefully label two $1.5 \mathrm{~mL}$ tubes, with Sense (Tube 1) and Antisense (Tube 2) and add the volume equivalent to $2.5 \mu \mathrm{g}$ purified plasmid to each.

2. Digest tube 1 with PstI and tube 2 with NcoI (see Note 6.4.b).

3. Spin down and incubate both tubes at $37^{\circ} \mathrm{C}$ for $15 \mathrm{~min}$ then stop the reaction by heating the tubes at $95^{\circ} \mathrm{C}$ for $5 \mathrm{~min}$.

4. Clean up the linearized plasmids (see Note 6.4.c). Quantify both the purified linearized plasmids by NanoDrop.

In the next step, the Roche Dig Labeling Kit will be used to synthesize and label the RNA probe in one single step. In the described procedure both control and detection probe will be synthesized. It is of outmost importance to provide high-quality template for the reaction to occur properly.

1. Add the equivalent of $1 \mu \mathrm{g}$ of purified linearized plasmid to a $200 \mu \mathrm{L}$ microtube. Place the microtube on ice and add the following reagents according to the mixing order (see Table 2).

2. Mix gently and incubate at $37^{\circ} \mathrm{C}$ for $2 \mathrm{~h}$. To stop the reaction add $2 \mu \mathrm{L}$ of $0.2 \mathrm{M}$ EDTA ( $\mathrm{pH} 8.0$ ) (see Note 6.4.d). Probes may be stored at $-20{ }^{\circ} \mathrm{C}$ for up to one year (see Note 6.4.e). 


\section{Table 2}

Probe synthesis reaction mixture order

\begin{tabular}{llll}
\hline Vial & Reagent & Volume, $\mu \mathbf{L}$ & Mixing order \\
\hline n.a. $^{a}$ & RNase-free PCR grade $\mathrm{H}_{2} \mathrm{O}$ & To 20 & 1 \\
\hline 8 & $10 \times$ Transcription buffer & 2 & 2 \\
\hline 10 & Protector RNase inhibitor & 1 & 3 \\
\hline 7 & $10 \times$ NTP labeling mixture & 2 & 4 \\
\hline For sense probe & & & \\
\hline 11 & RNA polymerase T7 & 2 & 5 \\
\hline For antisense $_{\text {probe }}$ & RNA polymerase SP6 & & \\
\hline 12 & & 2 & 5 \\
\hline
\end{tabular}

${ }^{\mathrm{a}}$ Sigma, W1754

${ }^{\mathrm{b}}$ According to pGEM insert orientation

3.4.3 Probe Labeling Quantification (Please See Note 6.4.f.)
Now determine the labeling efficiency, as it may be inconsistent. This step will ensure the control of the reaction and allows for normalizing the probe for the future hybridization essays. The simplest way to determine the labeling efficiency is to compare the probe that we synthesized to standard solution, a standard solution is provided as a control in the previously used labeling kit. An efficiency test is proposed in the kit instructions, but we find it to be overcomplicated and more expensive. The following approach consists of simply comparing the diluted standard to a dilution of our probe to find out with some degree of precision the concentration of our probe.

1. Make three tenfold dilutions of the probe in RNA dilution buffer, 4\% Paraformaldehyde $6 \times$ SSC in $\mathrm{H}_{2} \mathrm{O}$ (see Buffers 2.1.2), starting with $1 \mu \mathrm{L}$ of probe. And make 4 tenfold dilutions with the labeled RNA control standard, supplied with the kit (vial 5 ). Pipet $1 \mu \mathrm{L}$ of the original solutions followed by $1 \mu \mathrm{L}$ of all dilutions on a nylon membrane (see Note 6. 4.g).

2. Fix the nucleic acid to the membrane by cross-linking with UV-light or baking for $30 \mathrm{~min}$ at $120^{\circ} \mathrm{C}$.

3. Place the membrane strip in a $50 \mathrm{~mL}$ conical tube. Block for 5 min with $10 \mathrm{~mL} \mathrm{5 \%} \mathrm{BSA} \mathrm{(Materials} \mathrm{3.6),} \mathrm{in} \mathrm{an} \mathrm{orbital} \mathrm{shaker}$ with mild agitation. Discard the blocking solution and incubate for $90 \mathrm{~min}$ at room temperature with a solution of $1 / 1000$ of anti-digoxigenin antibody conjugated to alkaline phosphatase (Sigma, Al 054), in 1\% (w/v) BSA.

4. Wash three times for $10 \mathrm{~min}$ with PBS (Materials 1.3 ), in an orbital shaker 80 r.p.m. Drain thoroughly and transfer to a Petri dish. Add $5 \mathrm{~mL}$ of $\mathrm{NBT}^{-B_{C I P}{ }^{\circledR}}$ solution (sigma, 
72091), cover with aluminum foil and place in an orbital shaker at 80 r.p.m. Let react until the last dilution of the control starts to appear. Stop the reaction by washing out the NBT-BCIP ${ }^{\circledR}$ solution with ${ }_{\mathrm{dd}} \mathrm{H}_{2} \mathrm{O}$.

5. Compare the labeling of the probe with the scale made using the RNA-labeled control (see Note 6.4.h).

\section{In Situ Hybridization}

\subsection{Fixation}

The pistils will be prepared to undergo hybridization with the probe previously set, in two steps: First the pistils will be fixated and then the cells permeabilized to permit the probe penetration, and finally the hybridization and detection reaction will be performed.

Dissecting the ovaries prior to the fixation will help with the fixation, probe penetration and visualization of the final results. The formaldehyde fixation will allow to preserve the tissues, reduce the activity of proteins and help to unfold the target mRNA.

1. Select flowers and extract pistils. Place the pistil on a piece of double-faced duct tape on a microscopy slide. Under a stereoscope remove the valves of the pistil using fine gauge needles (G26 or higher) and fine point tweezers, by cutting along the valve suture ridges. Be careful not to sever the ovules from the septum and maintain the transmitting tissue intact (Fig. 2).
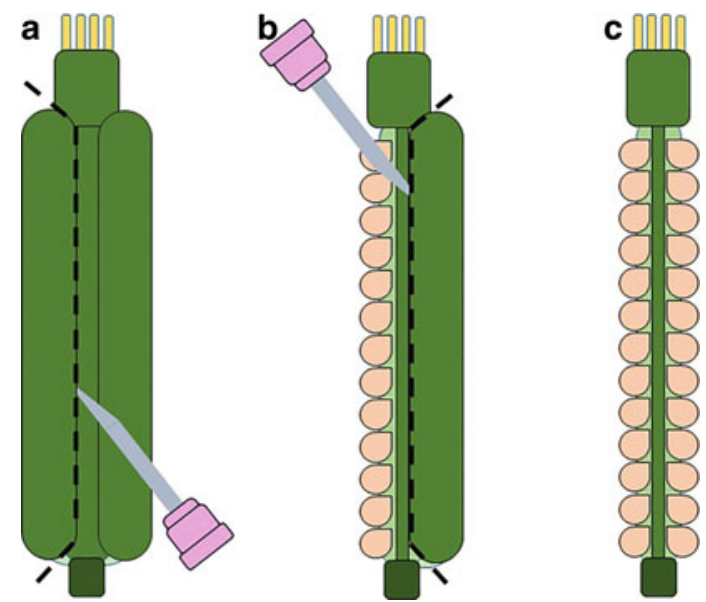

Fig. 2 Pistil dissection. To expose the ovules of the Arabidopsis pistil, place the pistil on a piece of double-faced duct tape so that the valve sutures on one of the sides face the top (a). With a G26 gauge hypodermic needle make a shallow incision following the suture line exposing the ovules. Proceed in the same manner on the other side (b). Finally using a pair of fine-tip tweezers pull the semidetached valves and finish cutting the opposite side of valve suture detaching it from the pistil (c) 
4.2 Slide Preparation

4.2.1 Slides Wash (See

Note 6.5.a)

4.2.2 Polylysine Coating

4.2.3 Permeabilization

4.2.4 Pistil Adhesion to the Coated Slides
2. Immediately immerse the samples in ice-cold fixative solution, 4\% Paraformaldehyde $0.001 \%$ Tween 20 in PBS (see Solutions 2.3.7). Apply sustained vacuum of $-70 \mathrm{KPa}$ for $15 \mathrm{~min}$ to help the fixative to penetrate into tissues. Maintain in the fixative solution for $18 \mathrm{~h}$ or overnight at $4{ }^{\circ} \mathrm{C}$.

3. Wash the fixed pistils by immersing them for $10 \mathrm{~min}$ in cold PBS, with mild agitation. Repeat three times. If necessary, preserve the dissected fixed pistils at $4{ }^{\circ} \mathrm{C}$ in $0.1 \%$ Paraformaldehyde in PBS until use, to avoid reversion of paraformaldehyde fixation.

To address the preparation of the slides for the hybridization, some protocols call for the use of extremely expensive slides or hybridization chambers. We propose the use of simple and affordable multiwell Teflon coated diagnostic slides, which restrict reagents to tissue samples, with some good cleaning and polylysine coating.

1. Place the slides in a staining rack and cover with a cleaning solution, $70 \%$ Ethanol $0.1 \%$ Triton X100, with mild agitation for $20 \mathrm{~min}$.

2. Wash the slides by dipping the staining rack in ${ }_{d d} \mathrm{H}_{2} \mathrm{O}$ with mild agitation for $10 \mathrm{~min}$. Repeat this process four times. Carefully dry the rack before dipping briefly in $100 \%$ ethanol and let the slides dry out in a dust free environment.

1. Place the clean slides in a clean $12 \times 12 \mathrm{~cm}$ square Petri dish.

2. Make a solution of $0.001 \%(\mathrm{w} / \mathrm{v})$ poly-L-lysine (Sigma P4707) in ${ }_{\mathrm{dd}} \mathrm{H}_{2} \mathrm{O}$.

3. Cover each well of the slides with $50 \mu \mathrm{L}$ of the poly-L-lysine solution.

4. Place the closed Petri dishes in a $40{ }^{\circ} \mathrm{C}$ oven overnight to dry the solution.

5. Keep the coated slides at room temperature in a dust-free environment (see Note 6.5.b).

Permeabilize the pistils to ease penetration of the probe; by first fixing the pistils to the poly-L-lysine-coated slides and then dehydrate, rehydrate, digest briefly with a cell wall-degrading enzyme cocktail and finally dehydrate for storage or immediate processing.

1. Transfer up to two fixed dissected pistils to each polylysine coated well (see Note 6.5.c).

2. Let air-dry for $20 \mathrm{~min}$ at room temperature and immediately proceed to the dehydration step. 
4.3 DehydrationRehydration and Mild Cell Wall Enzymatic Digestion

\subsection{Hybridization}

1. Dehydrate by incubating for 5 min with an increasing concentration series of methanol in PBS, 30\%, 50\%, 70\% 100\%. Then rehydrate by incubating for $5 \mathrm{~min}$ with a decreasing concentration series of methanol in PBS, 70\%, 50\%, 30\%. And finally for 5 min in PBS (see Note 6.6.a).

2. Transfer to a humidity box and immediately cover the pistils with $30 \mu \mathrm{L} 2 \%$ Macerozyme (cat.no. 28302, SERVA Germany) in PBS. Seal the humidity box with Parafilm and incubate for $60 \mathrm{~min}$ at $45^{\circ} \mathrm{C}$.

3. Remove the Macerozyme solution and wash with PBS three times, $5 \mathrm{~min}$ each. Then, incubate each well with $30 \mu \mathrm{L}$ proteinase $\mathrm{K}(20 \mu \mathrm{g} / \mathrm{mL})$ for $20 \mathrm{~min}$ at $37^{\circ} \mathrm{C}$. Then wash three times with PBS for $5 \mathrm{~min}$.

4. Wash with ${ }_{\mathrm{dd}} \mathrm{H}_{2} \mathrm{O}$ for $5 \mathrm{~min}$ (see Note 6.6.b).

5. Dehydrate again in an increasing series of methanol in PBS. Make an additional incubation with $100 \%$ methanol, and leave to air-dry.

6. Slides can be immediately used or stored in a dry sealed box at $-20{ }^{\circ} \mathrm{C}$ for up to 2 years (see Note 6.6.c).

To proceed to the final stage of the protocol, hybridization and detection, first the previously dehydrated tissues are incubated with the labeled probe, and finally the hybridized probe is detected by immunolocalization of digoxigenin.

1. Prepare a hybridization box, by placing a few conical tube caps with formamide at the bottom of a humidity box (see Note 6.7.a).

2. After selecting the correct amount of probe to use (see Note 6.7.b).

3. Calculate the volume of hybridization solution that you will require, about $25 \mu \mathrm{L}$ per well and prepare your hybridization buffer $(300 \mathrm{mM} \mathrm{NaCl}, 10 \mathrm{mM}$ Tris/EDTA, $1 \times$ Denhart's solution, $50 \%$ formamide, $10 \%$ dextran sulphate, $200 \mu \mathrm{g} / \mathrm{mL}$ tRNA) accordingly (see Buffers 1.4).

4. Place all aliquots required on ice and allow thawing.

5. Place the dextran sulfate aliquot in a $75{ }^{\circ} \mathrm{C}$ water bath for $15 \mathrm{~min}$, as it is highly viscose, it will also help to pipette with a clipped tip. Place the unfrozen tRNA stock aliquot in boiling water for $15 \mathrm{~s}$ before adding to the hybridization buffer.

6. Mix all volumes from the stocks according to the mixing order in Table 2 (seeBuffers 1.4).

7. Mix the hybridization buffer with the appropriate probe volume.

8. Add $25 \mu \mathrm{L}$ of the hybridization solution to each well; take care to not put different probes in adjacent wells. 
9. Cover the wells with a small piece of Parafilm ${ }^{\circledR}$, place the slide in the modified humidity chamber and seal with Parafilm ${ }^{\circledR}$. Incubate at $50{ }^{\circ} \mathrm{C}$ overnight. The Parafilm ${ }^{\circledR}$ pieces will ensure appropriate contact between tissue samples and probe, making a small hybridization chamber over tissues and avoiding the reagents evaporation during the incubation.

4.4.1 Posthybridization Washing
Extract the excess probe which has not hybridized with samples (see Fig. 3d).

1. Remove the conical tube caps containing formamide from the humidity chamber and carefully remove the Parafilm ${ }^{\circledR}$ covering the wells with fine tips forceps (see Note 6.7.c).

2. Wash four times for $2 \mathrm{~min}$ with $4 \times \mathrm{SSC}$ at room temperature.

3 . Wash four times for 2 min with $2 \times$ SSC at room temperature.
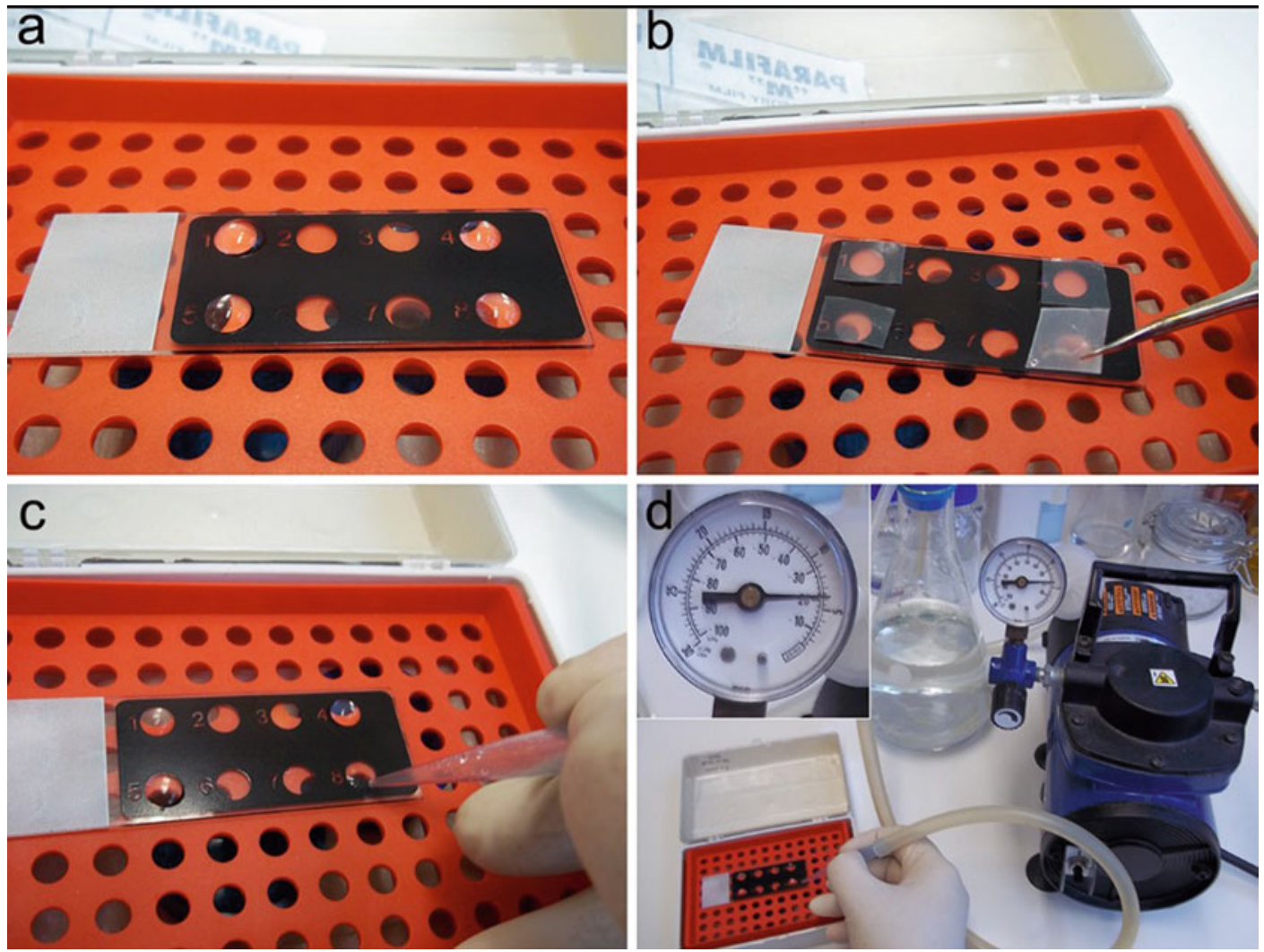

Fig. 3 Hybridization tips. Place the slides in a humidity chamber to avoid evaporation of solutions; additionally different probes can be used on the same slide if some space is left between wells; for example antisense probe is applied to wells 1 and 5 and control probe can be applied to wells 4 and 8 (a). Small squares of Parafilm ${ }^{\circledR}$ can be used to cover the wells to avoid excessive evaporation of hybridization solution (b). A pipette tip attached to a vacuum pump, under low negative pressure $(-20 \mathrm{KPa})$, can be used to swiftly remove solutions from the wells (d), speeding the wash steps 
4. Wash two times for $15 \mathrm{~min}$ with $0.1 \times \mathrm{SSC}$ at $50{ }^{\circ} \mathrm{C}$. These stringency conditions are standard, but they can be adjusted depending on the probe sequence to detect; lower stringency with lower temperature and higher SSC concentration allows hybridization between sequences that are less similar.

5. Finally wash with PBS for $5 \mathrm{~min}$.

\subsection{Immuno- localization of the Hybridized Probe}

The final step is the immunolocalization.

1. Place your slides in a humidity box.

2. Incubate samples in wells for 5 min with $5 \%(\mathrm{w} / \mathrm{v}) \mathrm{BSA}$ at room temperature to block nonspecific reactive groups of tissues.

3 . Incubate for $90 \mathrm{~min}$ at room temperature with the primary antibody, mouse anti-digoxigenin (Sigma, 11333062910), in a solution of $1 / 5000$ in $1 \%(w / v)$ BSA.

4. Wash three times for $5 \mathrm{~min}$ with $1 \%(\mathrm{w} / \mathrm{v})$ BSA.

5 . Incubate for $45 \mathrm{~min}$ at room temperature, with the secondary antibody, anti-mouse conjugated with FITC (Sigma, F0257), in a solution of $1 / 25$ in PBS (see Note 6.7.d).

6. Wash six times for 3 min with PBS.

7. Stain for $5 \mathrm{~min}$ with about $20 \mu \mathrm{L}$ of a $0.3 \mathrm{mM}$ DAPI solution in PBS (see Note 6.7.e).

8. Then wash six times for 3 min each time with PBS and mount the slides with Mowiol [29, 30].

9. Observe under fluorescence or confocal microscope (see Note 6.7.f).

\section{Controls}

To all assays the following tests must be considered to verify and validate the specificity of the hybridization probe and also of the antibodies used.

1. In situ hybridization using the sense probe. This control evaluates the unspecific binding of the probe. The results should be negative, with no detectable hybridization.

2. Immunolocalization replacing the primary anti-DIG antibody by buffer. This control evaluates the unspecific binding of the secondary antibody. No signal should be detected.

3. Immunolocalization replacing the secondary fluorescentlabeled antibody by buffer. This control evaluates if there is any source of unspecific autofluorescence, which may contaminate the results. No autofluorescence results should be detected in the range of the fluorescent-labeled antibody. 


\section{Notes}

\subsection{DNA Extraction Notes}

\section{2 pGEM Cloning} Notes
This crude DNA extraction method is a cheap and fast way to purify DNA.

It is not as efficient as other commercially available solutions. However, this protocol employs readily available reagents and provides DNA suitable for PCR.

(a) It is important to avoid using too much plant material.

(b) If too much material is used, it will result in an increase of gDNA degradation by interfering with the buffer denaturing capacity. It will also make it difficult to separate the DNA containing supernatant from the plant material debris.

In contrast this same method can be used to extract PCR suitable DNA from a smaller sample, like a single cotyledon, in which case all volumes should be reduced by $50 \%$ and DNA precipitation (Step 3) should be performed at $-20{ }^{\circ} \mathrm{C}$ with final centrifugation at $4{ }^{\circ} \mathrm{C}$.

(c) At this stage, the samples can be kept at room temperature for up to $\mathrm{l} \mathrm{h}$ with no major damage to the genomic DNA, while you finish other samples that you may be preparing.

(d) You may find that some RNA have been copurified, it should not be a problem for normal PCR. However, if necessary treat by adding $1 \mu \mathrm{L}$ of RNase solution (miniprep solution 4 , see Solutions 2.3.5) and incubate at $37^{\circ} \mathrm{C}$ for $20 \mathrm{~min}$.

The pGEM cloning system lets you easily clone regular PCR products without any additional complicated steps.

(a) Most common PCR enzymes will leave a $3^{\prime}$ adenine overhang, which is necessary for pGEM cloning. Error rate for a small amplicon are low. However, if you prefer to use a proofreading enzyme verify that they have $3^{\prime}$ adenylation activity or perform this as an additional step.

(b) Assuming a probe size of $750 \mathrm{bp}$ and a 3:1 ratio molar of insert to linearized plasmid.

The pGEM cloning system should perform perfectly with a wide range of insert-to-linearized plasmid ratios. However, if you experience difficulties with the ligation, try to increase the amount of insert.

(c) Use $0.5 \mathrm{~mL}$ tubes with low DNA binding capacity. In alternative regular PCR grade $200 \mu \mathrm{L}$ may also be used.

(d) The pGEM vector features a polylinker flanked by MI3 sites. You may use this feature to select plasmids that were recombined with the insert in a desirable manner. To do so, select plasmids by PCR using primers Ml3 forward and the reverse primer used to generate your insert. 


\subsection{Miniprep Protocol}

\subsection{RNA Probe Synthesis and Labeling}

Always select T7 to SP6 RNA polymerase ligation site insert oriented plasmids, this avoids confusion during synthesis of the RNA probe. Because of our selection T7 RNA polymerase always synthesizes Sense (or control) probe and SP6 RNA Polymerase always produce the antisense (detection) probe.

(a) Use $50 \mathrm{~mL}$ tubes as they provide better oxygenation, which will promote growth. This process can be scaled up. Most importantly, avoid letting your culture growth for too long.

(b) Two tubes may be used simultaneously to pellet down the bacterial cells, reducing the need for a counterweight in centrifugations and speeding the process, the two pellets can be joined at the resuspension step.

(c) It is best to leave some supernatant than to risk transferring of any the white precipitate. If it is too difficult to do so centrifuge again.

(d) It is of primordial importance to not disturb the phases and only transfer the aqueous upper phase, it is best to lose some than to contaminate your plasmid extract. If however you unfortunately transferred some of the other phases simply repeat step 6 and 7 .

(a) Assume that you selected a plasmid that features an insertion with the orientation T7 to SP6. In this way SP6 polymerase will produce an antisense probe and $\mathrm{T} 7$ will produce the sense probe. Therefore, henceforth, to avoid confusion, we will use the term sense for the probe synthesized with T7 RNA polymerase and antisense to the probe synthesized with SP6 RNA polymerase. If you choose to do otherwise, it is of little importance; just adjust accordingly.

(b) The use of fast digest enzymes is of course optional. But it saves a lot of time to this already long procedure. To further speed and simplify the process a thermocycler may use to act as an incubator, simply perform the restriction on $200 \mu \mathrm{L}$ tubes.

(c) Use a simple PCR purification kit (Like, Thermo K0701 "GeneJET PCR Purification Kit"), to remove enzymes and salts. Make sure to make the final elution with $20 \mu \mathrm{L}$ of RNasefree $\mathrm{H}_{2} \mathrm{O}$. Run $1 \mu \mathrm{L}$ in an agarose gel to check for nicked or supercoil plasmid, as both these forms can cause disruptions on the probe synthesis process.

(d) RNA synthesis quality should be verified by running $1 \mu \mathrm{L}$ of the reaction next to the labeled control (Vial 5) in an agarose gel electrophoresis with ethidium bromide staining. A good RNA synthesis results in a simple band. If a smear is observed, the reaction was probably contaminated with RNase and/or 
the RNase Inhibitor was not added to the reaction mix. If multiple bands are visible, then most probably the plasmid linearization and purification step failed, please repeat steps 2 4 and check for nicked or coiled plasmid.

(e) RNA probes are easily degraded. To preserve the probe avoid thawing and freezing cycles; for a longer preservation consider making aliquots.

(f) It is very important to determine the labeling efficiency, as it may be inconsistent. Several times we observed different probe yields in technical replicates; furthermore, it is useful to determine the probe concentration. So that the correct amount is used in the hybridization solution.

(g) Spot immediately to avoid degradation of the probe; space the spots so that they do not overlap. It is best to have the scale and the test probe side by side for easy comparison. Figure 4 is an example of what the spot distribution should look like.

(h) The labeled control standard dilution will allow you to determine the relative concentration of your probe (see Fig. 4).

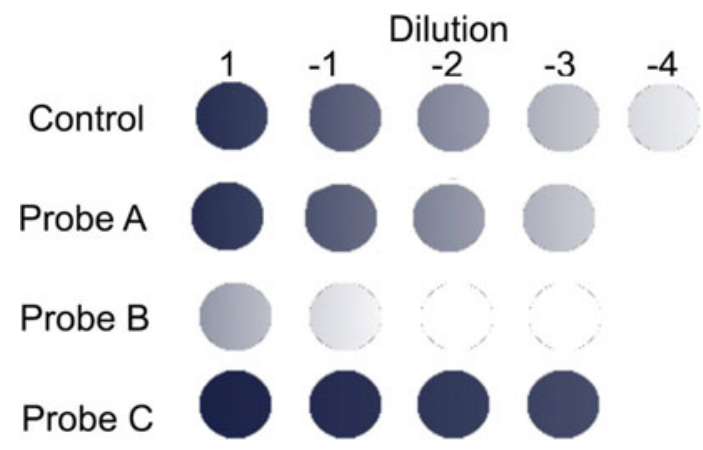

Fig. 4 Dot blot distribution example. This is an example of a dot blot comparing the five dilutions of the control probe with three test probes. The 5 tenfold dilutions of the control probe correspond to $1 \mu \mathrm{g} / \mu \mathrm{L}-0.1 \mu \mathrm{g} / \mu \mathrm{L}-0.01 \mu \mathrm{g} / \mu$ $\mathrm{L}-0.001 \mu \mathrm{g} / \mu \mathrm{L}-0.0001 \mu \mathrm{g} / \mu \mathrm{L}$, from left to right. This scale can be used to determine the approximate concentration of your labeled probe. If the fourth spot of your probe matches the color of the fourth spot of the control probe then your probe has a concentration of approximately $1 \mu \mathrm{g} / \mu \mathrm{L}$, like for Probe $\mathrm{A}$, but if by the time the higher dilution of the control starts to appear the last spot of your probe is still not visible, use the last spot for your probe and multiply by a factor of -10 fold for each missing spot. For Probe $B$ if the first spot is similar to the fourth spot of the control then it has the relative concentration of $0.001 \mu \mathrm{g} / \mu \mathrm{L}$. However, if like in the case of Probe $\mathrm{C}$, the last spot is similar to a lower dilution of the control, a multiplication of tenfold must be applied for each spot to the left, in this case $1 \mathrm{mg} / \mu \mathrm{L}$ 
6.5 Slide Preparation

6.6 Dehydration-rehydration and mild enzymatic digestion of cell wall (a) This step is especially important when reusing slides or if they seem to be dirty.

High-quality coating on the slides is of outmost importance, as it is what will insure that solutions do not spread and mix between wells. A good slide quality is one of the key issues for this technique. Slides can be cleaned and reused; just let them soak in a solution of ethanol $30 \%$ with some detergent for a couple of hours and gently brush them with a soft tooth brush, just prior to using this wash method. There are a lot of solution changes in this protocol. Although it is timeconsuming to prepare the polylysine-coated slides, it will help significantly to keep the pistils in place [31].

(b) Polylysine-coated slides can be prepared in advance, and if stored in a sealed rack at $-20{ }^{\circ} \mathrm{C}$ they can be preserved for up to 1 year without losing their properties. Just let them reach room temperature before opening to avoid the accumulation of condensation. Always inspect the slides under the microscope, to check the coating and cleaning, before use.

(c) Some humidity must be present at the surface of the dissected pistils to promote adhesion to the polylysine-coated slides, but avoid transferring too much fixative solution as it will take a long time to dry. A good way to get rid of the excess moisture is to lightly touch with a lint-free tissue, before placing the pistils on the slide.

(a) Going up the methanol dehydration series it is unfortunately very common for some material to loosen from the polylysine coating, please proceed with special care. If necessary do not hesitate to reposition the pistils in the reaction wells. When using higher concentrations of methanol take care not to let the solution evaporate. If necessary add more solution during incubation.

(b) Plant cell walls are the principal barrier for the penetration of the Probe. Partial digestion of them will not only facilitate the penetration of the probe but also will help with the removal off unlinked probe thus reducing nonspecific labeling.

(c) Make sure to store slides with pretreated/dried samples in small batches in clean air tight containers and also let them reach room temperature before opening the container, to avoid water condensation on samples. A cheap and easy way to prepare an airtight container is to put up to 4 slides in a $12 \times 12 \mathrm{~cm}$ square Petri dish and seal it with a double layer of Parafilm. 


\subsection{Hybridization}

(a) A humidity box is a versatile tool that can be purchased, or built, to maintain a saturated atmosphere around the slides avoiding the evaporation of solutions. We always build our humidity boxes by placing a few damp paper towels to bottom of a tip box. See Fig. 1 for how to build a simple reusable humidity chamber that also can be used for routine immunofluorescence.

(b) Use 20-100 ng of probe for each $1 \mathrm{~mL}$ of hybridization solution. Please note that some consideration and assays should be performed to ascertain the perfect amount of probe to use. Consider the expression level of the gene and the concentration of the probe. Assuming that your labeled probe has a concentration of near to $20 \mu \mathrm{g} / \mu \mathrm{L}, 1 / 20$ or $1 / 50$ ratio of probe to hybridization buffer is usually a good starting point to detect an averagely expressed gene. However, most probably you will need to make adjustments on the quantity of probe to use. If you do not get any labeling with this standard dilution, double the amount of probe until you do. Do the inverse if you get too much background with the antisense Probe.

(c) It is not unusual that some material may stick to the Parafilm ${ }^{\circledR}$, make sure to check the Parafilm ${ }^{\circledR}$ before discarding. If you do find that some material did stick to the Parafilm ${ }^{\mathbb{R}}$ use your forceps to place it back in the well.

(d) This proportion is for genes with an average expression. When the signal is very weak the quantity of probe used in the hybridization buffer must be adjusted. Genes with low expression are always more difficult to detect.

(e) DAPI should only label the intact nucleus a bright blue and therefore will act as one of the controls for integrity of the tissue as well as control for the specificity of the probe, as they should not overlap. Always check your DAPI solution before staining your slides. It is not uncommon for the DAPI solution to degrade before the expected expiration date, and it is very difficult to wash out (see Fig. 5).

(f) Use DAPI and FITC filter setting to detect the signals. Plant cell walls have autofluorescence at almost every wavelength; for the best results use a confocal microscope if possible. Set the excitation Laser to $355 \mathrm{~nm}$ for DAPI and $488 \mathrm{~nm}$ for FITC. Emission filters between 450 and $460 \mathrm{~nm}$ for DAPI, and for FITC 515-525 nm. If you use an epifluorescence microscope set the filters to Excitation/Emission $(\mathrm{nm})^{358} / 461$ for DAPI and $485 / 530$ for FITC. 

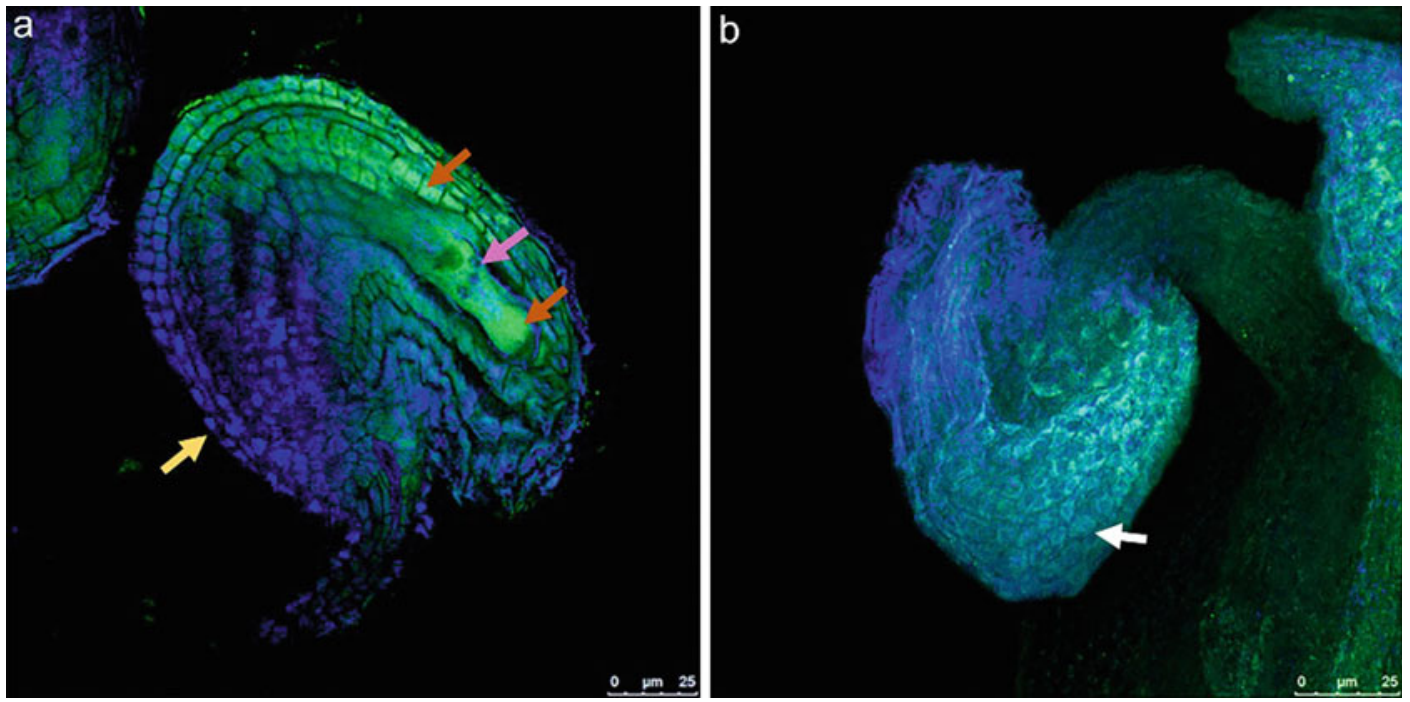

Fig. 5 Examples of results of confocal whole-mount FISH (fluorescent in situ hybridization) in Arabidopsis pistils. Examples of ovules after hybridization with the same AtAGP12 probe and counterstained with DAPI. On the left a perfectly preserved ovule was stained with a fresh solution of DAPI (a), on the right the ovule was not treated with paraformaldehyde and was stained with an old DAPI solution (b). The probe should only hybridize with the RNA present in the cell cytoplasm, giving a clear bright green image of the cells were the transcript is present (orange arrows), and should not be seen on the nucleus (pink arrow). DAPI stain is more than just a counterstain, it also serves to verify the conservation of the tissues. In perfectly preserved tissues the DAPI stain should be restricted to the cell's nucleus (yellow arrows), in poorly preserved or degenerated tissues DAPI stain spreads to the cytoplasm (white arrow) and it is very common for the probe to be detected along the cell wall (b). Spoiled DAPI solution will stain the cell walls (b)

\section{Acknowledgments}

This work was financed by FEDER through the COMPETE program, and by Portuguese National funds through FCT, Fundação para a Ciência eTecnologia (Project PTDC/AGR-GPL/115358/ 2009 and FCT - 02-SAICT-2017 - POCI-01-0145-FEDER027839) and PhD grant SFRH/BD/111781/2015), and received support from Spanish-Portuguese Joint Project $\mathrm{N}^{\circ}$ E 30/12. EU project 690946 'SexSeed' (Sexual Plant Reproduction - Seed Formation) funded by H2020-MSCA-RISE-2015.

\section{References}

1. Showalter AM (2001) Arabinogalactanproteins: structure, expression and function. Cell Mol Life Sci 58:1399-1417

2. Pereira AM, Nobre MS, Pinto SC, Lopes AL, Costa ML, Masiero S, Coimbra S (2016) "Love is strong, and you're so sweet":
JAGGER is essential for persistent synergid degeneration and polytubey block in Arabidopsis thaliana. Mol Plant 9:601-614

3. Costa ML, Sobral R, Ribeiro Costa MM, Amorim MI, Coimbra S (2015) Evaluation of the presence of arabinogalactan proteins and 
pectins during Quercus suber male gametogenesis. Ann Bot 115:81-92

4. Pereira AM, Masiero S, Nobre MS, Costa ML, Solís MT, Testillano PS, Sprunck S, Coimbra S (2014) Differential expression patterns of arabinogalactan proteins in Arabidopsis thaliana reproductive tissues. J Exp Bot 65:5459-5471

5. El-Tantawy AA, Solís MT, Da Costa ML, Coimbra S, Risueño MC, Testillano PS (2013) Arabinogalactan protein profiles and distribution patterns during microspore embryogenesis and pollen development in Brassica napus. Plant Reprod 26:231-243

6. Coimbra S, Almeida J, Junqueira V, Costa ML, Pereira LG (2007) Arabinogalactan proteins as molecular markers in Arabidopsis thaliana sexual reproduction. J Exp Bot 58:4027-4035

7. Pilling E, Höfte $\mathrm{H}$ (2003) Feedback from the wall. Curr Opin Plant Biol 6:611-706

8. Knox JP (1997) The use of antibodies to study the architecture and developmental regulation of plant cell walls. Int Rev Cytol 171:79-120

9. Lopes AL, Costa ML, Sobral R, Costa MM, Amorim MI, Coimbra S (2016) Arabinogalactan proteins and pectin distribution during female gametogenesis in Quercus suber L. Ann Bot 117:949-961

10. Coimbra S, Costa M, Jones B, Mendes MA, Pereira LG (2009) Pollen grain development is compromised in Arabidopsis agp6 agpl1 null mutants. J Exp Bot 60:3133-3142

11. Coimbra S, Costa M, Mendes MA, Pereira AM, Pinto J, Pereira LG (2011) Early germination of Arabidopsis pollen in a double null mutant for the arabinogalactan protein genes AGP6 and AGP11. Sex Plant Reprod 23:199-205

12. Xu Y, Gan ES, Ito T (2014) Misexpression approaches for the manipulation of flower development. Methods Mol Biol 1110:383-399

13. McDougall JK, Dunn AR, Jones KW (1972) In situ hybridization of adenovirus RNA and DNA. Nature 236:346-348

14. Javelle M, Marco CF, Timmermans M (2011) In situ hybridization for the precise localization of transcripts in plants. J Vis Exp 57:e3328

15. Biffo S, Tolosano E (1992) The use of radioactively labelled riboprobes for in situ hybridization: background and examples of application. Liver 12:230-237

16. Simmons D, Arriza J, Swanson L (1989) A complete protocol for in situ hybridization of messenger RNAs in brain and other tissues with radio-labelled single-stranded RNA probes. J Histotechnol 12:169-181
17. Komminoth P (1992) Digoxigenin as an alternative probe labeling for in situ hybridization. Diagn Mol Pathol 1:142-150

18. Höltke HJ, Ankenbauer W, Mühlegger K, Rein R, Sagner G, Seibl R, Walter T (1995) The digoxigenin (DIG) system for non-radioactive labelling and detection of nucleic acids - an overview. Cell Mol Biol 41:883-905

19. Gandrillon O, Solari F, Legrand C, Jurdic P, Samarut J (1996) A rapid and convenient method to prepare DIG-labelled RNA probes for use in non-radioactive in situ hybridization. Mol Cell Probes 10:51-55

20. Kiyama H, Emson PC (1991) An in situ hybridization histochemistry method for the use of alkaline phosphatase-labeled oligonucleotide probes in small intestine. J Histochem Cytochem 39:1377-1384

21. Testillano PS, Risueño MC (2009) Tracking gene and protein expression during microspore embryogenesis by confocal laser scanning microscopy. In: Touraev A, Forster BP, Mohan Jain S (eds) Advances in haploid production in higher plants. Springer, London, pp 339-347

22. Solís MT, Rodríguez-Serrano M, Meijón M, Cañal MJ, Cifuentes A, Risueño MC, Testillano PS (2012) DNA methylation dynamics and METla-like gene expression changes during stress-induced pollen reprogramming to embryogenesis. J Exp Bot 63:6431-6444

23. Solís MT, Berenguer E, Risueño MC, Testillano PS (2016) BnPME is progressively induced after microspore reprogramming to embryogenesis, correlating with pectin de-esterification and cell differentiation in Brassica napus. BMC Plant Biol 16:176

24. Tanious FA, Veal JM, Buczak H, Ratmeyer LS, Wilson WD (1992) DAPI (4',6-diamidino-2phenylindole) binds differently to DNA and RNA: minor-groove binding at AT sites and intercalation at AU sites. Biochemistry 31:3103-3112

25. Edwards K, Johnstone C, Thompson C (1991) A simple and rapid method for the preparation of plant genomic DNA for PCR analysis. Nucleic Acids Res 19:1349

26. Melton DA, Krieg PA, Rebagliati MR, Maniatis T, Zinn K, Green MR (1984) Efficient in vitro synthesis of biologically active RNA and RNA hybridization probes from plasmids containing a bacteriophage SP6 promoter. Nucleic Acids Res 18:7035-7056

27. Schenborn ET, Mierendorf RC Jr (1985) A novel transcription property of SP6 and T7 
RNA polymerases: dependence on template structure. Nucleic Acids Res 17:6223-6236

28. Feliciello I, Chinali G (1993) A modified alkaline lysis method for the preparation of highly purified plasmid DNA from Escherichia coli. Anal Biochem 212:394-401

29. Longin A, Souchier C, French M, Bryon PA (1993) Comparison of anti-fading agents used in fluorescence microscopy: image analysis and laser confocal microscopy study. J Histochem Cytochem 41:1833-1840

30. Osborn M, Weber K (1982) Immunofluorescence and immunocytochemical procedures with affinity purified antibodies: tubulincontaining structures. Methods Cell Biol 24:97-132

31. Sitterley G (2008) Poly-L-lysine cell attachment protocol. BioFiles 3:8-12 